\title{
PENGGUNAAN BERBAGAI CUT-OFF \\ INDEKS MASSA TUBUH SEBAGAI INDIKATOR OBESITAS TERKAIT PENYAKIT DEGENERATIF DI INDONESIA
}

\author{
Heryudarini Harahap ${ }^{1}$; Yekti Widodo ${ }^{1}$ dan Sri Mulyati ${ }^{1}$ \\ 1)Pusat Penelitian dan Pengembangan Gizi dan Makanan, Badan Penelitian dan Pengembangan \\ Kesehatan, Depkes
}

\section{ABSTRACT \\ DETERMINING CUT-OFF POINTS OF BODY MASS INDEX FOR OBESITY ASSOCIATED WITH DEGENERATIVE DISEASES IN INDONESIA}

Obesity now is recognized as a public health problem. Changing diets and decreasing physical activity explain the increasing prevalence of obesity. Method that is commonly used for indentifying obesity is Body Mass Index (BMI). At present, there has been a growing debate on different BMI cut-off points for different ethnic groups, in particular for Asian population. A different cut-off point is needed due to evidence associated with BMI, percentage of body fat, and body fat distribution that differ across population. Therefore, health risks may incrase even below the cutoff point of $25 \mathrm{~kg} / \mathrm{m} 2$ that now categorized as overweight. The objective of the study was to determine BMI cut-off points and their relationship with degenerative diseases. Data was originally taken from Health National Household Health Survei (SKRT) in 2004. The population were those who were aged 25 to 65 years old. The variable analysed statistically were age, sex, blood pressure, total cholesterol, and Diabetes Mellitus (DM). The analysis used in this study was univariate and bivariate tables to answer the objective. Based on WHO cut-off point, obesity was in $\mathrm{BMI} \geq 25 \mathrm{~kg} / \mathrm{m} 2$, and the prevalence of being hypertension, DM and hyperkolestrolemia as risks were $52.3 \%, 12,7 \%$ and $1,6 \%$ respectively. However, based on International Obesity Task Force (IOTF) cut-off in which pre obesity was started on BMI $23 \mathrm{~kg} / \mathrm{m} 2$, the prevalence of each risk was consecutively $40,1 \% ; 11,4 \%$ and $0,6 \%$. Respectively cut-off used by Ministry of Health in obesity was $25 \mathrm{~kg} / \mathrm{m} 2$ with prevalence for each risk was $50.2 \%, 11.8 \%$ and $1.5 \%$ respectively. Sensitivity (Se) and Specificity (Sp) were around 22.0-23.0 for all subjects based on sex, age, and education. The highest Se and Sp was found on hypercholesterol. Logistic regresion analysis showed that the increasing of BMI cut-off of 23 to 25 would be followed by the increase of the risk of hypercholesterol up to 0.6 points. On the other hand, decreasing BMI from $>25$ to $<25$ in USA may reduce $13 \%$ co-morbidity disease associated to obesity. In conclusion this study showed that on $\mathrm{BMI} \leq 23.5$ was related to degenerative diseases. However, the cut-off point still need to be examined in relation to the incidence of degenative diseases.

Key Word: body mass index, cut-off point, degenerative diseases

\section{PENDAHULUAN}

besitas adalah suatu keadaan penumpukan lemak tubuh yang berlebih, sehingga berat badan seseorang jauh di atas normal dan dapat membahayakan kesehatan; sedangkan overweight (kelebihan berat badan) adalah keadaan yang mana BB seseorang melebihi normal. Obesitas atau kegemukan terjadi karena ketidakseimbangan antara energi yang masuk dan energi yang keluar.

Pengukuran untuk menentukan kegemukan bisa dilakukan dengan berbagai cara yaitu antropometri, bioelectrical impedance, atau regional fat distribution. Pengukuran antropometri untuk obesitas diantaranya adalah berat badan 
dibandingkan umur, berat badan dibandingkan dengan tinggi badan, lingkar pinggang, atau lingkar panggul.

Metoda yang banyak digunakan untuk mengukur tingkat obesitas adalah Indeks Massa Tubuh (IMT) atau BMl (Body Mass Index), yang didapat dengan cara membagi berat badan $(\mathrm{kg})$ dengan kuadrat dari tinggi badan (meter). Nilai IMT yang didapat tidak tergantung pada umur dan jenis kelamin. Keterbatasan IMT adalah tidak dapat digunakan bagi 1) Anak-anak dalam masa pertumbuhan, 2) Wanita hamil, dan 3) Orang yang sangat berotot, contohnya atlit. Istilah "normal", "overweight" dan "obese" dapat berbeda-beda pada masingmasing negara dan budaya. Oleh karena itu,

WHO menetapkan suatu pengukuran/ klasifikasi obesitas yang tidak bergantung pada bias-bias kebudayaan. Para ahli sedang memikirkan untuk membuat klasifikasi IMT tersendiri untuk penduduk Asia. Hasil studi di Singapura memperlihatkan bahwa orang Singapura dengan IMT 27 - 28 mempunyai lemak tubuh yang sama dengan orang-orang kulit putih dengan IMT 30.

Pada Tabel 1 dapat dilihat klasifikasi Berat Badan yang diusulkan berdasarkan IMT pada orang Eropa menurut WHO pada tahun 1995 1), orang Asia menurut International Obesity Task Force (IOTF) dan WHO (2), dan Indonesia menurut Depkes RI 3).

Tabel 1

Batas IMT untuk orang Eropa, Asia dan Indonesia

\begin{tabular}{|l|l|l|l|l|l|}
\hline \multicolumn{2}{|c|}{ Eropa } & \multicolumn{2}{c|}{ Asia } & \multicolumn{2}{c|}{ Indonesia } \\
\hline $\begin{array}{c}\text { Keadaan } \\
\text { Gizi }\end{array}$ & $\mathrm{IMT}\left(\mathrm{Kg} / \mathrm{m}^{2}\right)$ & $\begin{array}{c}\text { Keadaan } \\
\text { Gizi }\end{array}$ & $\mathrm{IMT}\left(\mathrm{Kg} / \mathrm{m}^{2}\right)$ & Keadaan Gizi & $\mathrm{IMT}\left(\mathrm{Kg} / \mathrm{m}^{2}\right)$ \\
\hline & & & & Kurus sekali & $<17,0$ \\
\hline Kurus & $\leq 18,5$ & Kurus & $\leq 18,5$ & Kurus & $17,0-18,4$ \\
\hline Normal & $18,5-24,9$ & Normal & $18,5-22,9$ & Normal & $18,5-25,0$ \\
\hline Kegemukan & $\geq 25$ & Kegemukan & $\geq 23$ & Gemuk & $25,1-27,0$ \\
\hline Pre obes & $25,0-29,9$ & Pre obes & $23,0-24,9$ & Gemuk sekali & $>27,0$ \\
\hline Obes I & $30,0-34,9$ & Obes I & $25,0-29,9$ & & \\
\hline Obes II & $35,0-39,9$ & Obes II & $\geq 30,0$ & & \\
\hline Obes III & $\geq 40,0$ & & & & \\
\hline
\end{tabular}

IMT dapat digunakan untuk menentukan seberapa besar seseorang dapat terkena resiko penyakit tertentu yang disebabkan karena berat badannya. Pada orang India, peningkatan IMT dari 22 menjadi 24 dapat meningkatkan prevalensi Diabetes Mellitus menjadi 2 kali lipat, dan prevalensi ini naik menjadi 3 kali lipat pada orang dengan IMT $28{ }^{4)}$.

Hasil penelitian di Taiwan dengan menggunakan data Nutrition and Health Survey pada 4956 orang dewasa menunjukkan cut-off IMT < 24 untuk obesitas telah menunjukkan obesitas yang berkaitan dengan kelainan metabolik ${ }^{5)}$. Penelitian di Cina yang dilakukan pada 15239 orang Cina berumur 35-74 tahun juga menunjukkan hal yang sama yaitu cut-off IMT=24 dan lingkar pinggang $80 \mathrm{~cm}$ untuk laki-laki dan perempuan untuk penyakit terkait obesitas ${ }^{6)}$.

Proporsi bentuk tubuh orang Indonesia lebih mendekati penduduk Taiwan atau China, sehingga cut-off IMT yang dikemukakan oleh Depkes ${ }^{3}$ mungkin perlu dikaji lebih lanjut. Studi lebih lanjut tentang cut off IMT orang Indonesia sangat diperlukan sehingga risiko terkait obesitas dapat diturunkan.

Tujuan analisis adalah 1) menganalisis prevalensi obesitas dari berbagai cut-off IMT, dan 2) Menganalisis cut-off dari IMT yang berbeda terhadap risiko penyakit degeneratif. 


\section{BAHAN DAN CARA}

\section{Sumber Data dan Variabel}

Analisis dilakukan dengan menggunakan data sekunder dari Survei Kesehatan Rumah Tangga tahun 2004. Populasi dalam analisis ini adalah penduduk yang berusia 25-65 tahun di seluruh wilayah Indonesia. Cara pengambilan sampel dan pengumpulan data dapat dilihat pada Buku Survei Kesehatan Rumah Tangga, Volume 1 $\left(\right.$ SKRT, 2004) ${ }^{7}$.

Variabel-variabel yang digunakan $\mathrm{d}$ antaranya adalah dari data SKRT, dan subsampel Susenas Modul. Data yang berasal dari SKRT adalah umur, jenis kelamin, status perkawinan, jenjang pendidikan, berat badan, tinggi badan, tekanan darah sistol, tekanan darah diastole, gula darah, dan total kolesterol.

IMT dihitung berdasarkan data berat badan dan tinggi badan dari masing-masing subjek. Selanjutnya variabel IMT akan dijadikan variabel terikat sedangkan variabel lainnya adalah variabel bebas.

Hipertensi dinyatakan jika angka sistol $\geq 140 \mathrm{mmHg}$ dan atau angka diastole $\geq 90$ $\mathrm{mmHg}$, hiperkolesterol adalah jika kadar kolesterol $\geq 250 \mathrm{~mm} \mathrm{Hg}$ dan diabetes jika kadar gula darah puasa $\geq 110 \mathrm{~mm} \mathrm{Hg}$.

\section{Analisis Data}

Data responden yang dianalisis adalah penduduk usia 25-65 tahun yang mempunyai data berat dan tinggi badan, tekanan darah, kolesterol, dan gula darah. Analisis data dilakukan secara univariat, dan bivariat. Analisa univariat bertujuan untuk mengetahui prevalensi obesitas dan berbagai penyakit degeneratif berdasarkan berbagai cut-off. Analisis bivariat bertujuan untuk mengetahui risiko penyakit degeneratif dengan cut-off IMT yang berbeda. Untuk mengetahui hal tersebut akan digunakan analisis sensitivitas dan spesifisitas. Odd ratio dihitung untuk mengetahui besarnya risiko penyakit degeneratif.

\section{HASIL}

\section{Prevalensi Hipertensi, Hiperkolesterol dan DM}

Jumlah total subjek yang berusia $25-65$ tahun adalah 9765 orang. Jumlah ini setelah dikurangi dengan subjek yang berusia di atas 65 tahun, subjek yang berpuasa $\leq 8$ jam, dan subjek yang sedang mengkonsumsi obat-obatan yang ada kaitannya dengan tekanan, gula, dan kolesterol darah.

Prevalensi hipertensi, hiperkolesterol dan DM cenderung semakin meningkat dengan semakin meningkatnya IMT (Gambar 1 dan 2). Pada cut-off yang digunakan oleh WHO (1998), berat badan lebih dimulai pada IMT $\geq 25 \mathrm{~kg} / \mathrm{m} 2$ dengan prevalensi hipertensi, DM, dan hiperkolesterol masingmasing adalah $52,3 \%, 12,7 \%$ dan $1,6 \%$. Sedangkan pada cut-off IOTF (2002) berat badan lebih (pre obes) dimulai pada IMT 23 $\mathrm{kg} / \mathrm{m} 2$ dengan prevalensi untuk masingmasing adalah $40,1 \%, 11,4 \%$ dan $0,6 \%$. Cutoff yang digunakan oleh Depkes RI (2003) yaitu $>25 \mathrm{~kg} / \mathrm{m}^{2}$ dengan prevalensi untuk masing-masing faktor risiko adalah $50,2 \%$, $11,8 \%$ dan $1,5 \%$. 

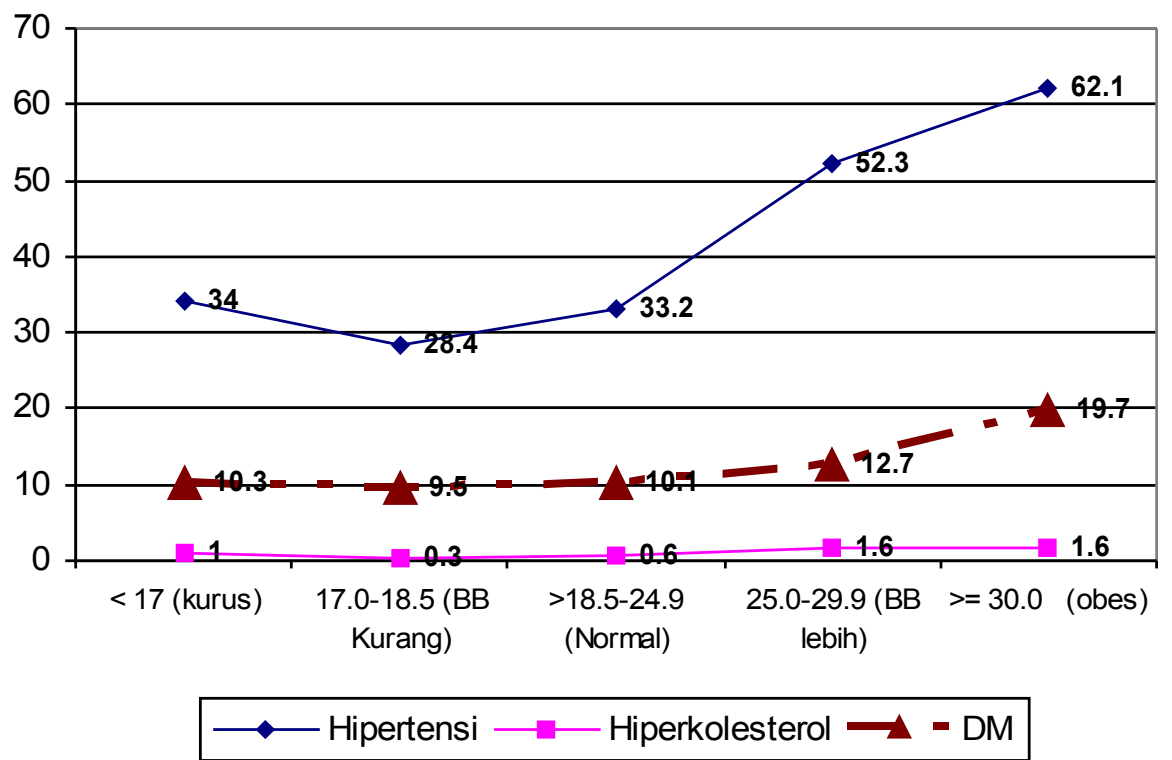

Gambar 1.

Prevalensi hipertensi, hiperkolesterol, dan diabetes mellitus dari cut off BMI menurut WHO

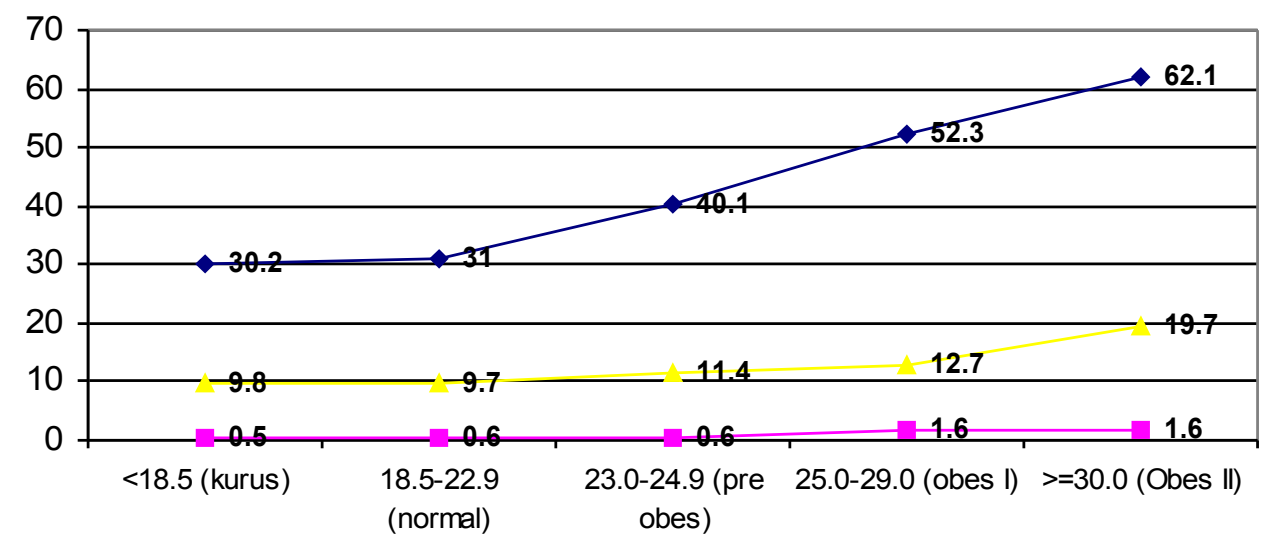

\section{$\multimap-$ Hipertensi $\rightarrow-$ Hiperkolesterol $\longrightarrow$ DM}

Gambar 2.

Prevalensi hipertensi, hiperkolesterol, dan diabetes mellitus dari cut off BMI menurut IOTF

Terlihat bahwa pada cut-off yang digunakan oleh WHO dan Depkes tidak terlalu berbeda, namun untuk cut-off yang digunakan oleh IOTF terdapat perbedaan 
yang cukup besar untuk prevalensi hiperkolesterol.

\section{Penggunaan cut-off IMT untuk penentuan obesitas}

Analisis dilakukan secara keseluruhan dari subjek, menurut jenis kelamin, usia dan pendidikan. Selain itu pada analisis juga dilakukan menurut merokok/tidak merokok, pengeluaran untuk buah dan sayur, dan aktivitas, namun tidak terdapat hasil yang bermakna.

Analisis Sensitivitas (Se) dan Spesifitas (Sp) dimulai dari cut-off IMT 22 sampai 30. Sebagai gold standar adalah keadaan tekanan darah, gula darah (DM) kolesterol total dan mempunyai satu atau lebih dari resikonya yaitu tekanan darah, gula darah, kolesterol total.

Tabel 2

Ringkasan hasil Se, Sp cut-off BMI menurut hipertensi, DM, hiperkolesterol, dan $\geq 1$ risiko

\begin{tabular}{|c|c|c|c|c|c|c|}
\hline \multirow{2}{*}{$\begin{array}{c}\text { Faktor Risiko } \\
\text { BMI }\end{array}$} & \multirow{2}{*}{ Se } & Sp & \multirow{2}{*}{ Area } & \multirow{2}{*}{$\mathrm{P}$} & \multicolumn{2}{|c|}{$95 \% \mathrm{Cl}$} \\
\cline { 5 - 7 } & & & & & Lower & Upper \\
\hline $\begin{array}{c}\text { Hipertensi } \\
22.0\end{array}$ & 58.5 & 56.5 & .575 & .000 & .563 & .587 \\
22.5 & 53.5 & 62.4 & .580 & .000 & .568 & .591 \\
23.0 & 48.4 & 67.2 & .583 & .000 & .571 & .595 \\
\hline DM & & & & & & \\
22.0 & 54.6 & 51.4 & .530 & .001 & .512 & .548 \\
22.5 & 49.9 & 57.1 & .535 & .000 & .517 & .553 \\
23.0 & 45.0 & 62.8 & .539 & .000 & .521 & .557 \\
\hline Hiperkolesterol & & & & & & \\
22.0 & 65.4 & 51.9 & .582 & .011 & .521 & .642 \\
22.5 & 61.7 & 56.5 & .591 & .005 & .530 & .653 \\
23.0 & 58.0 & 62.0 & .600 & .002 & .538 & .663 \\
\hline$\geq 1$ risiko & & & & & & \\
22.0 & 56.7 & 56.6 & .566 & .000 & .555 & .578 \\
22.5 & 51.7 & 63.7 & .572 & .000 & .560 & .584 \\
23.0 & 46.6 & 69.5 & .576 & .000 & .564 & .587 \\
& & & & & & \\
\hline
\end{tabular}

Hasil analisis Se dan Sp menunjukkan bahwa untuk hipertensi, DM, hiperkolesterol, dan $\geq 1$ risiko cut-off BMl berkisar antara 22.0 sampai 23.0. Pada hiperkolesterol menunjukkan nilai tertinggi untuk Se, Sp dan area under curve.

\section{a. Jenis Kelamin}

Pada Tabel 3 terlihat rata-rata nilai IMT, sistol, diastol, kolesterol dan gula darah. Hasil analisis menunjukkan antara laki-laki dan perempuan terdapat perbedaan yang signifikan pada variabel-variabel ini. Nilai $\mathrm{BMI}$, sistol, diastol, dan kolesterol lebih tinggi pada perempuan, sedangkan umur dan gula darah lebih tinggi pada laki-laki. Rata-rata umur untuk laki-laki adalah $41.85 \pm 10.68$ tahun, dan perempuan adalah $41.20 \pm 10.91$ tahun.

Tabel 4 memberikan gambaran tentang cut-off IMT pada laki-laki dan perempuan. Nilai Se pada laki-laki terlihat lebih rendah pada cut-off BMI 22-23 untuk faktor risiko hipertensi, DM dan $\geq 1$ risiko, sebaliknya pada nilai Se hiperkolesterol. Untuk hiperkolesterol, nilai Se, Sp tertinggi pada $\mathrm{BMI}=23$, dengan area under curve tertinggi 0,691. Pada perempuan, terlihat kecenderungan nilai Se dan Sp untuk semua faktor risiko hampir sama. Nilai cut-off BMI berkisar antara 22 dan 23 untuk hipertensi, DM dan $\geq 1$ risiko pada laki-laki dan 
perempuan, sedangkan nilai Se, Sp tertinggi

untuk hiperkolesterol perempuan adalah pada $\mathrm{BMI}=23,5$.

Tabel 3

Karakteristik faktor risiko metabolik menurut jenis kelamin

\begin{tabular}{|c|c|c|c|c|c|}
\hline \multirow[t]{2}{*}{ Variabel } & \multicolumn{2}{|c|}{ Laki-laki } & \multicolumn{2}{|c|}{ Perempuan } & \multirow{2}{*}{$\begin{array}{c}\mathrm{P} \\
\text { value }\end{array}$} \\
\hline & $\mathrm{N}$ & Mean \pm SD & $\mathrm{N}$ & Mean \pm SD & \\
\hline BMI (kg/m2) & 4551 & $21.81 \pm 3.17$ & 5214 & $23.08 \pm 4.19$ & 0.000 \\
\hline Sistol (mm Hg) & 4539 & $132.27 \pm 18.41$ & 5189 & $134.12 \pm 22.21$ & 0.000 \\
\hline Diastol $(\mathrm{mm} \mathrm{Hg})$ & 4539 & $81.33 \pm 11.89$ & 5189 & $84.2 \pm 14.62$ & 0.000 \\
\hline Kolesterol total (mg/dL) & 2163 & $170.49 \pm 20.49$ & 2969 & $176.03 \pm 25.00$ & 0.000 \\
\hline Gula darah puasa (mg/dL) & 4529 & $85.54 \pm 31.07$ & 5198 & $82.24 \pm 33.55$ & 0.000 \\
\hline
\end{tabular}

Tabel 4

Ringkasan hasil Se, Sp cut off BMI menurut hipertensi, DM, hiperkolesterol, 
dan $\geq 1$ risiko pada laki-laki dan perempuan

\begin{tabular}{|c|c|c|c|c|c|c|c|}
\hline \multirow[t]{2}{*}{ Jenis kelamin } & Faktor Risiko & \multirow[t]{2}{*}{$\mathrm{Se}$} & \multirow[t]{2}{*}{$\mathrm{Sp}$} & \multirow[t]{2}{*}{ Area } & \multirow{2}{*}{$\begin{array}{c}\text { value } \\
P\end{array}$} & \multicolumn{2}{|c|}{$95 \% \mathrm{Cl}$} \\
\hline & BMI & & & & & Lower & Upper \\
\hline \multirow[t]{16}{*}{ Laki-laki } & Hipertensi & & & & & & \\
\hline & 22.0 & 52.1 & 63.5 & .578 & .000 & .561 & .595 \\
\hline & 22.5 & 46.3 & 69.6 & .580 & .000 & .562 & .597 \\
\hline & 23.0 & 41.3 & 75.4 & .583 & .000 & .566 & .601 \\
\hline & DM & & & & & & \\
\hline & 22.0 & 49.4 & 59.2 & .543 & .001 & .518 & .568 \\
\hline & 22.5 & 44.0 & .348 & .546 & .000 & .521 & .571 \\
\hline & 23.0 & 39.3 & .291 & .551 & .000 & .526 & .576 \\
\hline & hiperkolesterol & & & & & & \\
\hline & 22.0 & 73.7 & 58.2 & .660 & .016 & .543 & .776 \\
\hline & 22.5 & 68.4 & 64.1 & .663 & .014 & .542 & .784 \\
\hline & 23.0 & 68.4 & 69.7 & .691 & .004 & .570 & .811 \\
\hline & $\geq 1$ risiko & & & & & & \\
\hline & 22.0 & 49.8 & 63.8 & .568 & .000 & .551 & .585 \\
\hline & 22.5 & 44.1 & 70.0 & .570 & .000 & .553 & .587 \\
\hline & 23.0 & 39.0 & 75.8 & .574 & .000 & .557 & .591 \\
\hline \multirow[t]{17}{*}{ Perempuan } & Hipertensi & & & & & & \\
\hline & 22.0 & 63.6 & 49.5 & .566 & .000 & .550 & .582 \\
\hline & 22.5 & 59.2 & 44.7 & .572 & .000 & .556 & .588 \\
\hline & 23.0 & 54.1 & 61.2 & .576 & .000 & .560 & .592 \\
\hline & $\mathrm{DM}$ & & & & & & \\
\hline & 22.0 & 60.9 & 44.6 & .528 & .043 & .501 & .554 \\
\hline & 22.5 & 56.9 & 50.0 & .534 & .011 & .508 & .561 \\
\hline & 23.0 & 52.0 & 55.7 & .538 & .005 & .512 & .565 \\
\hline & hiperkolesterol & & & & & & \\
\hline & 22.0 & 62.9 & 44.2 & .535 & .337 & .464 & .607 \\
\hline & 22.5 & 59.7 & 49.5 & .546 & .215 & .474 & .617 \\
\hline & 23.0 & 54.8 & 55.0 & .549 & .183 & .477 & .621 \\
\hline & 23.5 & 53.2 & 59.4 & .563 & .088 & .491 & .635 \\
\hline & $\geq 1$ risiko & & & & & & \\
\hline & 22.0 & 62.5 & 49.7 & .561 & .000 & .545 & .577 \\
\hline & 22.5 & 58.2 & 55.7 & .570 & .000 & .554 & .586 \\
\hline & 23.0 & 53.1 & 61.6 & .573 & .000 & .557 & .589 \\
\hline
\end{tabular}

b. Umur

Umur dibagi menjadi dua kelompok yaitu $<40$ tahun dan $\geq 40$ tahun. Rata-rata IMT untuk kedua kelompok umur tidak ada perbedaan, sedangkan untuk sistol, diastol, kolesterol dan gula darah terdapat perbedaan yang signifikan antara kelompok umur $<40$ tahun dan $\geq 40$ tahun (Tabel 5).

Tabel 5

Karakteristik faktor risiko metabolik menurut umur 


\begin{tabular}{|l|c|c|c|c|c|}
\hline \multirow{2}{*}{ Variabel } & \multicolumn{2}{|c|}{ Laki-laki } & \multicolumn{2}{c|}{ Perempuan } & Nilai \\
\cline { 2 - 5 } & $\mathrm{N}$ & Mean $\pm \mathrm{SD}$ & $\mathrm{N}$ & Mean $\pm \mathrm{SD}$ & $\mathrm{P}$ \\
\hline BMI $(\mathrm{kg} / \mathrm{m} 2)$ & 4647 & $22.48 \pm .65$ & 5026 & $22.48 \pm 3.97$ & 0.951 \\
Sistol $(\mathrm{mm} \mathrm{Hg})$ & 4633 & $126.59 \pm 15.44$ & 4633 & $139.28 \pm 22.78$ & 0.000 \\
Diastol $(\mathrm{mm} \mathrm{Hg})$ & 5002 & $81.00 \pm 11.49$ & 5002 & $84.61 \pm 14.86$ & 0.000 \\
Kolesterol total $(\mathrm{mg} / \mathrm{dL})$ & 2101 & $169.97 \pm 20.45$ & 2899 & $176.55 \pm 25.28$ & 0.000 \\
Gula darah puasa $(\mathrm{mg} / \mathrm{dL})$ & 4627 & $81.85 \pm 31.31$ & 4997 & $85.62 \pm 36.41$ & 0.000 \\
\hline
\end{tabular}

Tabel 6 memberikan gambaran tentang hasil ringkasan Se dan Sp dari berbagai faktor risiko menurut kelompok umur. Nilai $\mathrm{Se}, \mathrm{Sp}$ untuk DM lebih rendah dibandingkan hipertensi dan hiperkolesterol pada kelompok umur $<40$ tahun pada cut-off BMI
22-23. Pada usia $\geq 40$ tahun nilai Se dan $\mathrm{Sp}$ $\mathrm{BMI}$ cenderung lebih rendah dibandingkan dengan usia $<40$ tahun untuk semua faktor risiko. Nilai Se dan Sp untuk hiperkolesterol terlihat lebih tinggi dibandingkan hipertensi, DM dan $\geq 1$ risiko. 
Tabel 6

Ringkasan hasil Se, Sp cut off BMI menurut hipertensi, DM, hiperkolesterol, dan $\geq 1$ risiko pada umur $<40$ dan $\geq 40$ tahun

\begin{tabular}{|c|c|c|c|c|c|c|c|}
\hline \multirow{2}{*}{$\begin{array}{c}\text { Usia } \\
\text { (tahun) }\end{array}$} & \multirow{2}{*}{$\begin{array}{c}\text { Faktor Risiko } \\
\text { BMl } \\
\end{array}$} & \multirow[t]{2}{*}{ Se } & \multirow[t]{2}{*}{$S p$} & \multirow[t]{2}{*}{ Area } & \multirow{2}{*}{$\begin{array}{c}P \\
\text { Nilai }\end{array}$} & \multicolumn{2}{|c|}{$95 \% \mathrm{Cl}$} \\
\hline & & & & & & Lower & Upper \\
\hline \multirow[t]{16}{*}{$<40$} & Hipertensi & & & & & & \\
\hline & 22.0 & 62.3 & 54.9 & 586 & .000 & .568 & 605 \\
\hline & 22.5 & 58.2 & 61.1 & 598 & .000 & .578 & 615 \\
\hline & 23.0 & 52.7 & 67.0 & .598 & .000 & .580 & .617 \\
\hline & DM & & & & & & \\
\hline & 22.0 & 50.6 & 50.5 & .505 & .509 & .477 & .534 \\
\hline & 22.5 & 46.6 & 57.3 & 515 & .302 & .486 & 543 \\
\hline & 23.0 & 41.9 & 62.3 & .521 & .142 & .493 & .549 \\
\hline & Hiperkolesterol & & & & & & \\
\hline & 22.0 & 70.6 & 50.5 & 606 & .132 & .477 & .734 \\
\hline & 22.5 & 70.6 & 52.6 & 634 & .056 & .507 & .761 \\
\hline & 23.0 & 64.7 & 38.1 & .633 & .057 & .502 & 765 \\
\hline & $\geq 1$ risiko & & & & & & \\
\hline & 22.0 & 58.7 & 54.8 & .567 & .000 & .550 & .585 \\
\hline & 22.5 & 54.5 & 61.1 & .578 & .000 & .560 & .596 \\
\hline & 23.0 & 49.3 & 67.1 & .582 & .000 & .564 & 600 \\
\hline \multirow[t]{16}{*}{$\geq 40$} & Hipertensi & & & & & & \\
\hline & 22.0 & 56.7 & 58.6 & .576 & .000 & .560 & .592 \\
\hline & 22.5 & 51.2 & 64.1 & .577 & .000 & 561 & .593 \\
\hline & 23.0 & 46.4 & 69.9 & .581 & .000 & .565 & .597 \\
\hline & DM & & & & & & \\
\hline & 22.0 & 57.4 & 52.3 & .549 & .000 & .525 & .572 \\
\hline & 22.5 & 52.1 & 57.9 & .550 & .000 & .526 & .573 \\
\hline & 23.0 & 47.2 & 63.2 & .552 & .000 & .528 & .576 \\
\hline & Hiperkolesterol & & & & & & \\
\hline & 22.0 & 64.1 & 51.2 & .576 & .035 & .507 & 645 \\
\hline & 22.5 & 59.4 & 56.8 & .581 & .026 & .511 & 651 \\
\hline & 23.0 & 56.3 & 62.1 & .592 & .012 & .521 & 662 \\
\hline & $\geq 1$ risiko & & & & & & \\
\hline & 22.0 & 55.6 & 59.2 & .574 & .000 & .558 & .590 \\
\hline & 22.5 & 50.2 & 64.9 & .575 & .000 & .560 & 591 \\
\hline & 23.0 & 45.1 & 71.5 & .578 & .000 & .562 & 594 \\
\hline
\end{tabular}

Faktor Risiko dari Cut-off IMT yang berbeda

Pada Tabel 7 dapat dilihat besarnya faktor risiko dari penggunaan cut-off dari IMT 23 sampai 25 . Terlihat bahwa semakin tinggi cut-off IMT semakin tinggi untuk terkena hipertensi, DM dan hiperkolesterol. Peningkatan faktor risiko untuk hiperkolesterol dari cut-off IMT 23 menjadi 25 lebih besar dibandingkan dengan hipertensi, DM atau $\geq$ 1 risiko. 
Tabel 9

Nilai OR, dan $95 \% \mathrm{Cl}$ dari cut off IMT 23-25

\begin{tabular}{|l|c|c|c|}
\hline \multirow{2}{*}{$\begin{array}{c}\text { Faktor Risiko } \\
\text { BMI }\end{array}$} & \multirow{2}{*}{ OR } & \multicolumn{2}{c|}{$95 \% \mathrm{Cl}$} \\
\cline { 3 - 4 } & & Lower & Upper \\
\hline Hipertensi & & & \\
23 & 2.100 & 1.930 & 2.285 \\
24 & 2.268 & 2.074 & 2.480 \\
25 & 2.407 & 2.184 & 2.653 \\
\hline DM & & & \\
23 & 1.373 & 1.207 & 1.561 \\
24 & 1.446 & 1.265 & 1.652 \\
25 & 1.436 & 1.245 & 1.657 \\
\hline Hiperkolesterol & & & \\
23 & 1.934 & 1.247 & 3.000 \\
24 & 2.045 & 1.318 & 3.173 \\
25 & 2.682 & 1.723 & 4.174 \\
\hline$\geq 1$ Risiko & & & \\
23 & 1.946 & 1.791 & 2.115 \\
24 & 2.126 & 1.945 & 2.323 \\
25 & 2.280 & 2.068 & 2.515 \\
\hline
\end{tabular}

\section{BAHASAN}

Prevalensi hipertensi, hiperkolesterol, diabetes berdasarkan cut-off yang digunakan oleh WHO (1) dan Depkes (3) tidak terlalu jauh berbeda, namun terdapat perbedaan yang cukup besar dengan prevalensi yang digunakan oleh IOTF, terutama untuk prevalensi hiperkolesterol. Cut-off yang digunakan Depkes (3) hampir sama dengan yang digunakan oleh $\mathrm{WHO}$ (1) yaitu $\mathrm{BMI}=$ atau > $25 \mathrm{~kg} / \mathrm{m} 2$ untuk menyatakan kegemukan. Menurut Weisell (8) cut-off yang digunakan WHO (1) adalah klasifikasi yang digunakan untuk orang Eropa dan merupakan cut-off point internasional pertama. Walaupun cut-off ini secara umum diterima di berbagai negara, namun sudah banyak negara yang mulai mempertanyakannya sehubungan dengan kesehatan masyarakat terutama di daerah Asia Pasifik. Secara umum orang Asia mempunyai persentase lemak tubuh lebih tinggi dibandingkan orang Eropa (Kaukasian) pada IMT yang sama. Orang Asia mempunyai rasio pinggang panggul lebih tinggi dari Kaukasian, dan mempunyai lemak tubuh lebih tersentralisasi, sebaliknya orang Eropa mempunyai massa otot lebih tinggi dibandingkan orang Asia. Kekurangan gizi pada saat di dalam kandungan, gaya hidup saat ini yang berhubungan dengan aktivitas fisik dan konsumsi serat rendah, dan genetik di antaranya merupakan faktor potensial dari etiologi phenomena ini.

Cut-off yang direkomendasikan untuk menentukan nilai IMT adalah yang mempunyai keseimbangan Sensitivitas dan Spesifitas terbaik. Hasil analisis ini menemukan untuk sampel secara keseluruhan nilai Se dan Sp terbaik dari hipertensi, gula darah atau $\geq 1$ risiko berada pada BMI 22,0, dan pada kolesterol pada nilai 22,5. Pada laki-laki, nilai Se kecil, kecuali untuk kolesterol yaitu pada IMT 23. Pada perempuan nilai Se dan Sp berada pada kisaran 22,5 sampai dengan 23,5, dengan cut- off tertinggi juga pada kolesterol. Untuk subjek yang berusia < 40 tahun subjek $\geq 40$ tahun nilai Se dan Sp adalah 22.5 23.0, dengan nilai tertinggi pada kolesterol. 
Dari analisis yang dilakukan yaitu menurut jenis kelamin, dan usia terlihat bahwa Se dan Sp untuk hiperkolesterol lebih tinggi dibandingkan dengan 3 parameter lainnya yaitu hipertensi, gula darah dan $\geq$ dari 1 risiko.

Tidak ada batas yang jelas dari IMT yang dapat menentukan ada atau tidak ada peningkatan untuk terkena penyakit tertentu misalnya penyakit jantung koroner, baik dibawah cut-off atau jika berada diatas cutoff tersebut dapat meningkatkan risiko terkena penyakit. Dari hasil analisis Se, Sp belum ada batas yang jelas dari IMT dalam hubungannya dengan faktor risiko, namun ada kecenderungan cut-off IMT 23,5 sudah mulai menunjukkan adanya risiko dari peningkatan tekanan darah, kolesterol dan gula darah. Masih sedikit studi yang menggunakan pendekatan sensitivitas dan spesifisitas terutama untuk penentuan IMT. Hasil analisis Pan (5) menunjukkan BMl < 24 terkait dengan penyakit di Taiwan, analisis lain yang dilakukan oleh Wildman (6) untuk penduduk China juga menyarankan IMT $<24$.

Hasil analisis dengan menggunakan regresi logistik menunjukkan peningkatan nilai cut-off IMT akan meningkatkan risiko terkena penyakit degeneratif. Sebagai contoh orang-orang yang mempunyai IMT > 23 mempunyai risiko terkena hipertensi 2,1 kali dibandingkan dengan orang yang mempunyai IMT $<23$, jika cut-off ditingkatkan menjadi 25 , maka risiko terkena hipertensi menjadi 2,4 kali. Risiko terkena hiperkolesterol meningkat 0,6 poin jika IMT dinaikkan dari 23 menjadi 25. Menurut $\mathrm{Pan}^{5}$ penurunan IMT dari $>25$ menjadi $<25$ pada orang-orang di USA dapat menghilangkan $13 \%$ dari penyakit yang terkait dengan obesitas.

Kekuatan dari analisis ini adalah menggunakan data Survei Kesehatan Nasional yang merupakan representatif dari total populasi orang dewasa di Indonesia, sehingga hasilnya dapat digeneralisasikan untuk populasi orang dewasa di Indonesia yang berusia $25-65$ tahun. Sebaliknya analisis ini berasal dari data cross-sectional, sehingga diperlukan meta analysis dari berbagai data, dan penelitian prospektif untuk meyakinkan bahwa diperlukan penurunan cut-off IMT untuk orang dewasa di Indonesia. Hasil analisis ini juga tidak mengukur secara langsung lemak tubuh atau distribusi lemak, karena IMT adalah untuk memprediksi lemak atau distribusi lemak tubuh. Studi lebih lanjut diperlukan untuk terhadap etnis yang berbeda dalam hubungannya dengan IMT, rasio lingkar pinggang panggul, lemak tubuh dan distribusi lemak tubuh.

\section{KESIMPULAN}

Hasil analisis data menunjukkan prevalensi hipertensi, gula darah dan kolesterol dengan menggunakan cut-off IOTF dan WHO pada masing-masing BMI 23 dan 25 tidak menunjukkan perbedaan yang besar. Menurut cut-off yang digunakan IOTF prevalensi hipertensi, DM, dan hiperkolesterol masing-masing adalah 40,1\%; $11,4 \%$ dan $0,6 \%$, dan menurut cut-off yang digunakan $\mathrm{WHO}$ adalah $52.3 \%, 12.7 \%$ dan $1.6 \%$ untuk masing masing resiko.

Nilai Se dan Sp berkisar antara 22-23.5 untuk subjek secara keseluruhan, atau menurut jenis kelamin, umur, dan pendidikan. Nilai dengan keseimbangan Se dan Sp tertinggi banyak terdapat pada hiperkolesterol. Hasil analisis data menunjukkan pada IMT 23 sudah mulai terjadi risiko penyakit degeneratif yang terkait dengan obesitas.

\section{SARAN}

Penurunan angka IMT dari 25 menjadi 23 secara nasional perlu dikaji lebih lanjut dengan meta analysis dari berbagai data yang tersedia. Penelitian prospektif juga perlu dilakukan untuk meyakinkan bahwa diperlukan penurunan cut-off IMT untuk orang dewasa di Indonesia. Hasil analisis ini juga tidak mengukur secara langsung lemak tubuh atau distribusi lemak, karena BMI adalah tidak untuk memprediksi lemak atau distribusi lemak tubuh. Studi lebih lanjut diperlukan untuk melihat etnis yang berbeda dalam hubungannya dengan BMI, rasio 
lingkar pinggang panggul, lemak tubuh dan distribusi lemak tubuh.

\section{RUJUKAN}

1. WHO. Physical status: the use and interpretation of anthropometry. Report of WHO Expert Committee. Geneva, World Health Organization, 1995

2. IOTF/WHO. The Asia Pacific perspective: redefining obesity and its treatment. Melbourne, Health Communication Australia. 2000.

3. Direktorat Gizi Masyarakat. 2003. Petunjuk teknis pemantauan status gizi orang dewasa dengan indeks massa tubuh (IMT). Dirjen Binkesmas. Depkes RI. Jakarta

4. www.obesindonesia. Prevalensi obesitas. Visited 21 Maret 2005.
5. Pan WH, et.al. 2004. Body mass index and obesity-related metabolic disorder in Taiwanese and US white and blacks: implications for definitions of overweight and obesity for Asians. Am J Clin Nutr ;79: 31-9.

6. Widlman RP, et.al. 2004. Appropriate body mass index and waist circumference cutoffs for categorization of overweight and central adiposity among Chinese adults. Am J Clin Nutr ;80: 29-36.

7. Survei Kesehatan Rumah Tangga. 2004. Vol 1 Rancangan Survei Kesehatan Rumah Tangga. Badan Penelitian dan Pengembangan Kesehatan, Depkes RI

8. Weisell RC. 2002. Body mass index as an indicator of obesity. Asia Pasific $\mathrm{J}$ Clin Nutr; 11 (suppl):S681-S684 